\title{
Faktor yang mempengaruhi ibu menyapih anak di bawah usia 2 tahun
}

\author{
Rika Yulendasari $^{1 *}$, Sumbara ${ }^{2}$, Redia Indira Putrianti ${ }^{3}$ \\ 1Program Studi IImu Keperawatan Fakultas Kedokteran Universitas Malahayati. \\ *Email: rikayulendasari@malahayati.ac.id \\ 2Prodi S1 Keperawatan Fakultas Keperawatan Universitas Bhakti Kencana. \\ ${ }^{3}$ Puskesmas Rawat Inap Way Kandis Kota Bandar Lampung
}

\section{Abstract \\ Practices of breastfeeding and weaning among mothers of children under 2 years old at Bandar Lampung-Indonesia}

Background: Weaning is a process for stopping breastfeeding gradually or at once. This process can be either because of the child herself wanting to stop breastfeeding or because the mothers desire, or by both of them for many reasons. Data from survey of health demography in Indonesia in 2017 showed that there were only $54.6 \%$ of children were receiving breastfeeding complete until 2 years old.

Purpose: Know the factors of practices of breastfeeding and weaning among mothers of children under 2 years old

Methods: A quantitative research by using Cross Sectional approach. Population was all mothers who has children under two years old. Samples were 145 respondents. Data were collected by using questionnaires and anthropometry. Data were analyzed by using Chi-Square Test.

Results: There were correlations of occupation ( $p$-value $0.025<a 0.05$ ) and $O R=2.7$, nutrition status ( $p$-value $0.006<a 0.05$ ) and $\mathrm{OR}=3.5$, and family support ( $\mathrm{p}$-value $0.002<a 0.05$ ) and $\mathrm{OR}=3.1$ on practices of breastfeeding and weaning among mothers of children under 2 years old

Conclusion: There were practices of breastfeeding and weaning among mothers of children under 2 years old. Suggestion to health worker and provider to improve health services especially promotion program and education for essential of breastfeeding until the children complete 2 years old.

\section{Keywords: Practices; Breastfeeding; Weaning; Mothers; Children under 2 years old.}

Pendahuluan: Menyapih adalah proses berhentinya masa menyusui berangsur-angsur atau sekaligus. Proses itu dapat disebabkan oleh si anak itu sendiri untuk berhenti menyusu atau bisa juga dari sang ibu untuk berhenti menyusui anaknya, atau keduanya dengan berbagai alasan.Berdasarkan data dari Survey Demografi Kesehatan Indonesia (SDKI) di tahun 2017, presentase anak yang mendapatkan ASI sampai usia 2 tahun hanya sebesar $54,6 \%$.

Tujuan: Diketahui faktor - faktor yang mempengaruhi ibu menyapih anak di bawah usia 2 tahun.

Metode: Penelitian kuantitatif dengan pendekatan cross sectional. Populasi pada penelitian ini adalah semua ibu yang memiliki anak di bawah usia 2 tahun. Sampel dalam penelitian ini sebesar 145 responden. Instrumen dalam penelitian ini dengan menggunakan lembar kuesioner dan antropometri. Uji statistik yang digunakan adalah uji Chi-Square.

Hasil: Terdapat hubungan pekerjaan dengan penyapihan pada anak dibawah usia 2 tahun ( $p$-value $=0,025<a$ $=0,05)$ serta nilai $O R=2,7$, status gizi ( $p$-value $=0,006<a=0,05)$ nilai $O R=3,5$, dan dukungan keluarga $(p-$ value $=0,002<\alpha=0,05)$ dan nilai $O R=3,1$.

Simpulan: Ada hubungan pekerjaan, status gizi, dan dukungan keluarga dengan penyapihan pada anak dibawah usia 2 tahun. Saran bagi petugas kesehatan untuk meningkatkan pelayanan dan memberikan penyuluhan terhadap ibu menyusui mengenai pentingnya pemberian ASI samapai usia anak 2 tahun.

Kata Kunci: Tindakan; Penyapihan; ASI; Anak dibawah 2 tahun 
Faktor yang mempengaruhi ibu menyapih anak di bawah usia 2 tahun

\section{PENDAHULUAN}

Pemberian asupan yang optimal sejak bayi adalah upaya yang paling efektif untuk meningkatkan kesehatan anak. Pada tahun 2006 diperkirakan 9,5 juta anak meninggal sebelum berusia 5 tahun dan dua per tiga kematian ini terjadi pada tahun pertama kehidupan anak. Dari berbagai penyebab kematian anak $35 \%$ berhubungan dengan kekurangan nutrisi/malnutrisi. Laporan WHO juga menyebutkan bahwa hampir $90 \%$ kematian balita terjadi di negara berkembang dan lebih dari $40 \%$ kematian tersebut disebabkan diare dan infeksi saluran pernafasan akut, yang dapat dicegah dengan pemberian ASI eksklusif (Monika, 2014).

Menyusui berarti menjalin kasih sayang ibu terhadap anak. Menyusui anak hingga usia 2 tahun adalah hal yang normal. Saat anak genap berusia 2 tahun, anak sudah siap untuk disapih dan lepas dari payudara ibu. Menurut American Academy of Family Physicians (AAFP) meningkatkan waktu menyusui memberikan keuntungan dalam hal kesehatan bagi anak dan juga ibu. Adapun penelitian yang dilakukan terhadap 250 balita di Kenya ditemukan hasil bahwa ASI rata-rata memenuhi 32\% kebutuhan energi anak, ASI juga memberikan kontribusi terhdap kebutuhan lemak dan vitamin A anak (Onyango, Celic, McCaffery, Boeke, \& Feinberg, 2002; Monika, 2014).

Resiko anak menderita suatu penyakit berkurang dimana komponen imunitas dalam ASI juga akan meningkat pada tahun kedua menyusui dan selama proses menyapih dimana ASI dapat mencegah hingga 10\% kematian anak usia di bawah 5 tahun (balita), keuntungan lainnya adalah intelektual, mental, dan sosial pada anak dapat berkembang dengan baik. Sedangkan tidak ada bukti bahwa menyapih anak usia 2 tahun dapat merugikan atau membahayakan kesehatan, perkembangan, dan psikologi anak (Monika, 2014).

World Health Organization (WHO) merekomendasikan penyapihn dilakukan setelah anak berusia 2 tahun. Pada usia ini anak sudah mempunyai pondasi kuat bagi perkembangan selanjutnya. Menurut beberapa penelitian komposisi ASI terus berubah hingga anak berusia 2 tahun dan masih tetap mengandung nutrisi penting yang berguna untuk membangun sistem kekebalan tubuh anak (Prasetyono, 2009; Ifalahma, 2016).
Menurut data UNICEF hasil Infant and Young Child Feeding pada tahun 2017 secara global didapatkan bahwa anak yang mendapat ASI sampai usia 1 tahun sebesar $71 \%$ dan anak yang mendapatkan ASI sampai usia 2 tahun sebesar 45\% (United Nations Children's Fund, 2018).

Berdasarkan data dari Survey Demografi Kesehatan Indonesia (SDKI) tahun 2017, presentase anak yang mendapatkan ASI sampai usia 1 tahun sebesar $74,7 \%$ dan presentase anak yang mendapatkan ASI sampai usia 2 tahun sebesar 54,6\%. Provinsi Lampung sendiri merupakan pronvinsi dua terbaik dari 10 provinsi yang ada di Sumatera yang mendapatkan presentase anak kurang dari 2 tahun yang tidak mendapatkan ASI sebesar 19,8\% (Badan Penelitian Statistik, 2018).

Dampak penyapihan ASI kurang dari 6 bulan akan menyebabkan hubungan anak dan ibu berkurang keeratannya karena proses bounding ettachment terganggu, insiden penyakit infeksi terutama diare meningkat, pengaruh gizi yang mengakibatkan malnutrisi pada anak, dan mengalami reaksi alergi yang menyebabkan diare, muntah, ruam dan gatal-gatal karena reaksi dari sistem imun (Nugroho, 2011).

Pemutusan pemberian ASI (penyapihan) dipengaruhi oleh beberapa faktor, yaitu faktor dari ibu, faktor dari anak dan faktor sikap. Salah satu faktor dari ibu adalah pekerjaan, seorang ibu yang sibuk bekerja berpengaruh pada kurangnya waktu dalam menyusui anak cenderung akan cepat melakukan penyapihan lebih awal, lalu faktor pengetahuan ibu tentang penyapihan juga sangat berperan, seorang ibu dengan pengetahuan baik tentang ASI dan waktu yang tepat untuk menyapih anaknya akan berpengaruh pada perilaku dalam penyapihan serta ibu yang mempunyai pengetahuan yang baik tentang manfaat ASI selama dua tahun bagi sang anak, dimungkinkan akan mempengaruhi waktu penyapihan pada anaknya (Marmi, 2012; Nugraheny \& Amalia, 2017).

Disamping itu juga status kesehatan ibu dapat mempengaruhi penyapihan seorang anak, yaitu ibu yang sakit cenderung kesulitan dalam memberikan ASI serta kualitas ASI yang berkurang. Berdasarkan faktor anak yaitu status gizi anak, anak sedang sakit, atau anak yang sedang tumbuh gigi. Berdasarkan faktor sikap yaitu bisa dari pengalaman pribadi, dari informasi yang diberikan

Rika Yulendasari ${ }^{i *}$, Sumbara ${ }^{2}$, Redia Indira Putrianti ${ }^{3}$

'Program Studi llmu Keperawatan Fakultas Kedokteran Universitas Malahayati. *Email: rikayulendasari@malahayati.ac.id

${ }^{2}$ Prodi Si Keperawatan Fakultas Keperawatan Universitas Bhakti Kencana.

${ }^{3}$ Puskesmas Rawat Inap Way Kandis Kota Bandar Lampung 
Faktor yang mempengaruhi ibu menyapih anak di bawah usia 2 tahun

oleh orang lain, serta kebudayaan yang ada disekitar ibu dan keluarga (Asuncion, \& Newman, 2007; Nugraheny \& Amalia, 2017).

Hasil penelitian Esti Nugraheny, Rizka Putri Amalia tahun 2017 yaitu menunjukkan sebagian besar ibu bekerja lebih dini dalam melakukan penyapihan $(67,9 \%)$ dengan ( $p$ - value 0,01 ), sebagian besar ibu dengan pengetahuan cukup melakukan penyapihan lebih dini $(47,5 \%)$ dengan ( $p$ - value 0,00 ), sebagian besar ibu dengan pendidikan rendah lebih dini dalam melakukan penyapihan $(64,3 \%)$ dengan ( $p$-value 0,00 ), namun pada faktor informasi tidak mempengaruhi waktu penyapihan dengan ( $p$ value 0,83). Ada pengaruh antara faktor pekerjaan, pengetahuan yang cukup, dan pendidikan yang rendah dengan waktu penyapihan, namun pada faktor informasi tidak signifikan mempengaruhi penyapihan.

Kota Bandar Lampung merupakan salah satu kabupaten yang ada di Provinsi Lampung. Cakupan ASI Eksklusif di Puskesmas Way Kandis hanya sebesar $33,54 \%$ dari target pencapaian sebesar $45 \%$ dimana menjadi urutan 3 terendah dari 30 puskesmas yang ada di Kota Bandar Lampung (Dinas Kesehatan Kota Bandar Lampung, 2018).

Berdasarkan data presurvey yang dilakukan peneliti di Wilayah Kerja Puskesmas Rawat Inap Way Kandis dengan melakukan wawancara terhadap 10 ibu yang mempunyai anak usia 2 tahun, dimana 6 ibu (60\%) mengatakan menyapih anaknya diusia kurang dari 2 tahun dan ada 4 ibu (40\%) menyapih anaknya diusia 2 tahun. Dari 10 ibu didapatkan 5 ibu (50\%) yang memiliki pekerjaan dan 5 ibu (50\%) tidak memiliki pekerjaan atau ibu rumah tangga. Dari 10 ibu ada 6 ibu (60\%) mengatakan kurang mengetahui tentang penyapihan pada anak, 4 ibu memiliki pengetahuan yang cukup tentang penyapihan pada anak. Ada 2 ibu (20\%) mengatakan anaknya mulai tumbuh gigi dan 4 ibu (40\%) yang mengatakan kurangnya dukungan dari keluarga terhadap proses penyapihan anak. Oleh karena itu peneliti tertarik untuk meneliti dan mengkaji lebih jauh masalah tersebut.

\section{METODE PENELITIAN}

Jenis penelitian kuantitatif, Survei Analitik dengan pendekatan Cross Sectional. Tempat penelitian di Puskesmas Rawat Inap Way Kandis Kota Bandar Lampung pada bulan Juni 2019. Populasinya sebanyak 228 orang dan sampel sebanyak 145 responden. Teknik pengambilan sampel dengan purposive sampling. Sampel diambil berdasarkan kriteria inklusi pada penelitian adalah Ibu yang memiliki anak berusia $2-2,5$ tahun, Ibu yang bisa membaca dan menulis, sehat jasmani dan rohani, dan bersedia menjadi responden.

Analisis univariat data pekerjaan, status gizi, dan dukungan keluarga terhadap penyapihan pada anak. Analisa bivariat untuk mengetahui ada tidaknya hubungan pekerjaan, status gizi, dan dukungan keluarga dengan penyapihan pada anak dibawah usia 2 tahun. Data primer diperoleh dari hasil jawaban atas lembar pertanyaan tentang penyapihan sebanyak 5 pertanyaan dan dukungan keluarga sebanyak 10 pertanyaan yang dibagikan kepada responden dengan instrument berupa kuesioner. Kategorisasi pengetahuan ibu tentang penyapihan ditentukan berdasarkan jawaban benar dengan batas $60 \%$ dari total skor.. Penilaian yang dilakukan pada status gizi dengan gizi kurang jika nilai pengukuran dengan antropometri $\mathrm{BB} / \mathrm{U}-3$ SD s/d < - $2 \mathrm{SD}$, sedangkan untuk kategori gizi baik jika nilai pengukuran sebesar -2 SD s/d 2 SD. Berdasarkan hasil uji validitas kuesioner penelitian dengan 20 responden ditunjukkan dari 15 butir pertanyaan dukungan keluarga tentang ASI eksklusif yang diuji cobakan, ternyata 10 butir tidak valid karena memiliki $r$ hitung $<r$ tabel (dimana $a=$ $5 \%, N=20$, jadi $r$ tabel $=0,332$ ), sehingga pertanyaan mengenai dukungan keluarga tentang ASI eksklusif yang dapat digunakan untuk mengumpulkan data penelitian sebanyak 10 butir pertanyaan. Hasil uji reliabilitas kuesioner penelitian untuk variabel dukungan keluarga tentang ASI eksklusif didapatkan Cronbach's Alpha $=0,930>0,6$, sehingga butir pertanyaan tentang dukungan keluarga sebanyak 10 adalah reliable. Penelitian ini sudah lulus kelaikan etik dari Komisi Etik Penelitian Kesehatan Universitas Malahayati pada 18 Juni 2019.

\footnotetext{
Rika Yulendasari ${ }^{1 *}$, Sumbara ${ }^{2}$, Redia Indira Putrianti ${ }^{3}$
}

'Program Studi llmu Keperawatan Fakultas Kedokteran Universitas Malahayati. *Email: rikayulendasari@malahayati.ac.id

${ }^{2}$ Prodi Si Keperawatan Fakultas Keperawatan Universitas Bhakti Kencana.

${ }^{3}$ Puskesmas Rawat Inap Way Kandis Kota Bandar Lampung 
Faktor yang mempengaruhi ibu menyapih anak di bawah usia 2 tahun

HASIL

Tabel 1. Karakteristik Responden $\mathrm{N}=145$

\begin{tabular}{lcc}
\hline Variabel & Frekuensi (f) & Persentase (\%) \\
\hline Usia & & \\
Reproduksi Tidak Sehat & 130 & 89.7 \\
Reproduksi Sehat & 15 & 10.3 \\
& & \\
Pendidikan & 15 & 10.3 \\
SD & 48 & 33.1 \\
SMP & 74 & 51.0 \\
SMA & 8 & 5.5 \\
Perguruan Tinggi & & \\
Penyapihan & 84 & 57.9 \\
Penyapihan Dini (<2 tahun) & 61 & 42.1 \\
Tidak penyapihan Dini ( $\geq 2$ tahun) & & \\
Pekerjaan & 39 & 26.9 \\
Bekerja & 106 & 73.1 \\
Tidak bekerja & & \\
Status Gizi & & \\
Gizi Kurang & 37 & 25.5 \\
Gizi Baik & 108 & 74.5 \\
Dukungan keluarga & & \\
Tidak mendukung penyapihan $\geq 2$ tahun & 78 & 53.8 \\
Mendukung penyapihan $\geq 2$ tahun & 67 & 46.2 \\
\hline
\end{tabular}

Berdasarkan Tabel 1. Distribusi frekuensi responden diketahui bahwa karakteristik usia ibu sebagian besar responden dalam rentang usia reproduksi sehat (20-35 tahun) yaitu sebanyak 130 responden (89,7\%). Usia mempengaruhi seseorang dalam upaya pemberian ASI. Bertambahnya usia seharusnya masyarakat mengetahui bahwa ASI sangat penting untuk bayi. Namun kenyataannya banyak yang melakukan penyapihan dini. Sesuai pernyataan jumlah produksi ASI selain dipengaruhi oleh diit ibu juga dipengaruhi masa laktasi, umur ibu, frekuensi menyusui dan psikis ibu. Ibu dengan umur yang lebih muda akan lebih banyak memproduksi ASI dibandingkan dengan ibu-ibu yang sudah tua. Umur merupakan faktor penting dalam mempengaruhi kemampuan seseorang dalam melakukan segala sesuatu (Soetjiningsih, 2004). Diketahui bahwa lebih dari separuh responden melakukan penyapihan dini yaitu sebanyak 84 responden $(57,9 \%)$.

Penyapihan merupakan istilah yang digunakan untuk menyebut priode transisi dimana bayi masih diberi makanan cair berupa ASI, tetapi juga secara bertahap diperkenalkan pada makanan padat (Manalu, 2008). Hasil penelitiaan ini didapatkan pekerjaan, sebagian besar responden tidak bekerja yaitu sebanyak 106 responden $(73,1 \%)$, responden yang bekerja sebanyak 39 responden $(26.9 \%)$. Bekerja bukan alasan untuk menghentikan pemberian air susu ibu ASI, pemberian air susu ibu ASI merupakan hal yang terbaik bagi bayi (Roesli, 2012). Hasil penelitian ini didukung oleh penelitian terkait, diketahui bahwa sebagian besar ibu yang bekerja menyapih anaknya pada usia 12 bulan dengan persentase tertinggi 19,6\%, dan untuk ibu yang tidak bekerja menyapih anaknya pada usia 22 bulan dengan persentase $12,5 \%$. Seorang ibu yang sibuk bekerja berpengaruh pada

Rika Yulendasari ${ }^{i *}$, Sumbara $^{2}$, Redia Indira Putrianti ${ }^{3}$

'Program Studi llmu Keperawatan Fakultas Kedokteran Universitas Malahayati. *Email: rikayulendasari@malahayati.ac.id ${ }^{2}$ Prodi Sı Keperawatan Fakultas Keperawatan Universitas Bhakti Kencana.

${ }^{3}$ Puskesmas Rawat Inap Way Kandis Kota Bandar Lampung 
Faktor yang mempengaruhi ibu menyapih anak di bawah usia 2 tahun

kurangnya waktu dalam menyusui anak sehingga cenderung akan cepat melakukan penyapihan lebih awal (Nugraheny \& Amalia, 2017).

Tabel 2. Hubungan Pekerjaan, Status Gizi, Dukungan Keluarga dengan Penyapihan N = 145

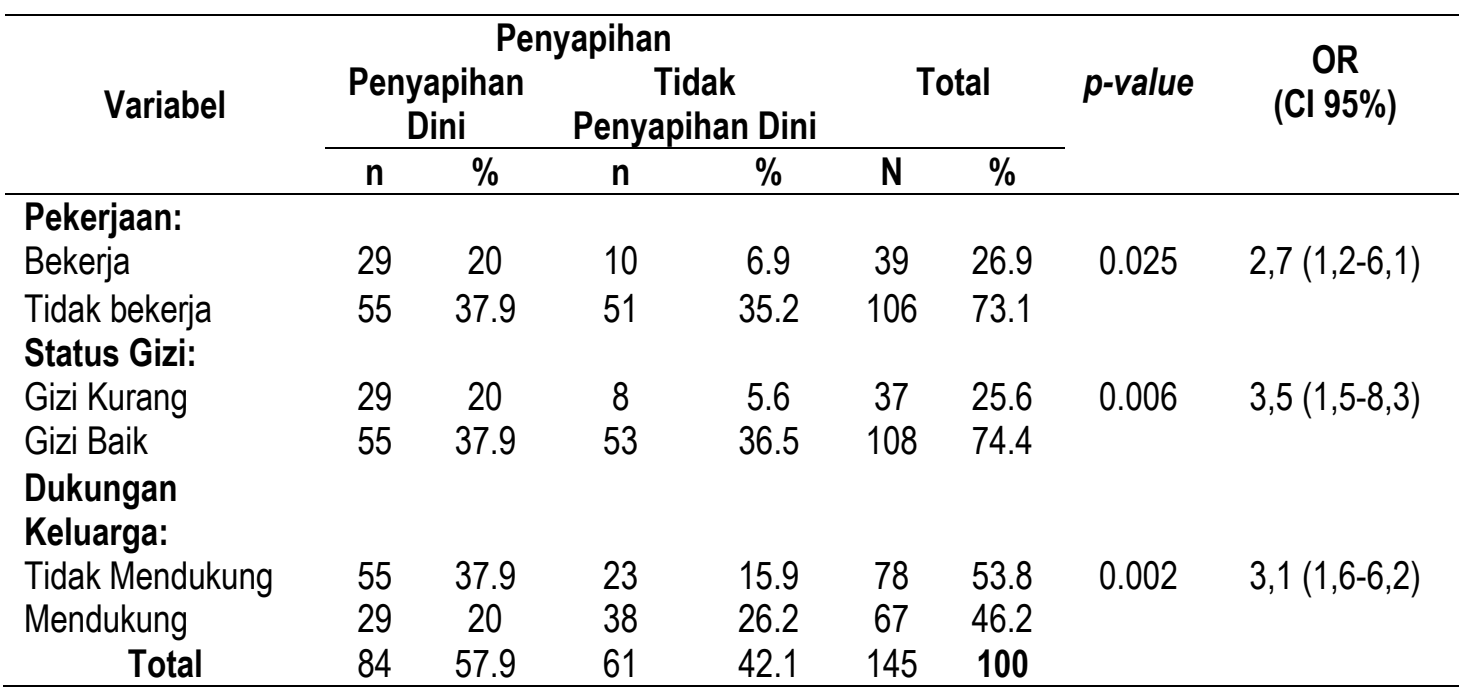

Berdasarkan hasil tabel 2. didapatkan bahwa dari 39 responden yang bekerja sebanyak 29 responden $(20 \%)$ melakukan penyapihan dini, sedangkan dari 106 responden yang tidak bekerja sebanyak 55 responden $(37.9 \%)$ melakukan penyapihan dini. Hasil uji chi square didapatkan nilai $p$ value 0,025 , artinya lebih kecil dibandingkan dengan nilai alpha $(0,025<0,05)$. Dengan demikian dapat disimpulkan secara statistik dengan derajat kepercayaan 95\%, diyakini terdapat hubungan bekerja dengan penyapihan pada anak di bawah usia 2 tahun. Sedangkan hasil uji OR diperoleh nilai 2,7 (Cl 95\% 1,2-6,1), artinya responden yang tidak bekerja berpeluang 2,7 kali lebih besar untuk melakukan penyapihan dini dibandingkan responden yang bekerja.

\section{PEMBAHASAN}

Distribusi frekuensi responden berdasarkan penddikan bahwa sebagian besar mempunyai pendidikan SMA sebanyak 74 responden $(51,0 \%)$. Pendidikan merupakan upaya untuk memberikan pengetahuan sehingga terjadi perubahan perilaku positif yang meningkat. Orang yang memiliki pendidikan yang baik memiliki kemampuan untuk menyerap dan memahami pengetahuan yang diterimanya. Semakin baik pendidikan seseorang, maka semakin mudah ia untuk menyerap dan memahami pengetahuan yang ia terima termasuk memahami pentingnya pemberian ASI secara eksklusif kepada anak berkaitan dengan pertumbuhannya (Wawan \& Dewi, 2010).

Berdasarkan status gizi, sebagian besar anak dengan status gizi baik yaitu sebanyak 108 responden $(74,5 \%)$, sedangkan anak yang memiliki status gizi kurang sebanyak 37 responden $(25,5 \%)$. Faktor yang mempengaruhi status gizi yaitu tingkat sosial ekonomi, tingkat pendidikan orang tua, jumlah anak dalam keluarga, umur penyapihan, pemberian makanan pendamping ASI yang terlalu dini, dan terlalu sering terkena penyakit infeksi (Supariasa, Bakri \& Fajar, 2012). Hasil penelitian tentang hubungan umur penyapihan dan pola asuh makan terhadap status gizi anak balita usia 25-36 bulan di Desa Purwosari Kabupaten Wonogiri dapat diketahui bahwa ada 36 anak balita yang memiliki status gizi normal. Dari 36 anak balita yang status gizinya normal tersebut ternyata 32 diantaranya disapih pada umur $\geq 24$ bulan. Hal ini membuktikan bahwa umur penyapihan yang tepat dapat mempengaruhi status gizi anak balita sehingga anak balita dapat memiliki status gizi normal (Hastuti, Muwakhidah \& Widowati, 2016).

Adapun dukungan keluarga, sebagian besar responden dengan keluarga tidak mendukung yaitu sebanyak 78 responden $(53,8 \%)$, sedangkan responden yang memiliki keluarga mendukung sebanyak 67 responden $(46,2 \%)$. Keluarga yang dapat melaksanakan tugas kesehatan dengan baik

Rika Yulendasari ${ }^{i *}$, Sumbara ${ }^{2}$, Redia Indira Putrianti ${ }^{3}$

'Program Studi llmu Keperawatan Fakultas Kedokteran Universitas Malahayati. *Email: rikayulendasari@malahayati.ac.id

${ }^{2}$ Prodi Si Keperawatan Fakultas Keperawatan Universitas Bhakti Kencana.

${ }^{3}$ Puskesmas Rawat Inap Way Kandis Kota Bandar Lampung 
berarti sanggup menyelesaikan masalah kesehatan keluarga. Selain keluarga mampu melaksanakan fungsi dengan baik, keluarga juga harus mampu melakukan tugas kesehatan keluarga. Salah satunya memanfaatkan fasilitas kesehatan yang ada disekitarnya. Keluarga bisa berkonsultasi dengan tenaga keperawatan untuk memecahkan masalah yang dialami anggota keluarganya, sehingga anggota keluarga dapat bebas dari segala macam penyakit (Mubarak \& Chayatin, 2009). Penelitian ini sejalan dengan penelitian terdahulu didapatkan $60,0 \%$ responden memiliki dukungan keluarga kurang dan $81,1 \%$ disapih di bawah 2 tahun. Berdasarkan uji statistik dengan Chi Square diperoleh nilai $p=0,002$ ( $p$ $<0,005$ ) yang berarti ada hubungan dukungan keluarga dengan usia sapih menyusui pada ibu yang bekerja di Desa Rowosari, Kecamatan Tembalang, Kota Semarang (Putri \& Zubaidah, 2017).

Jenis pekerjaan memengaruhi proses penyapihan. Pekerjaan informal atau tradisional seperti pertanian, pekerjaan domestik, industri, wiraswasta, dan buruh memiliki waktu yang fleksibel dan hal ini memberikan waktu untuk mengasuh anaknya termasuk menyusui sehingga usia penyapihannya bisa lebih lambat (Akter, \& Rahman, 2010).

Hasil penelitian ini selaras dengan hasil penelitian yang dilakukan tentang faktor-faktor yang berhubungan dengan waktu penyapihan pada anak di bawah dua tahun. Menunjukkan bahwa sebagian besar ibu bekerja lebih dini dalam melakukan penyapihan $(67,9 \%)$ dengan $p$ value 0,01 . Disimpulkan bahwa ada pengaruh antara faktor pekerjaan dengan waktu penyapihan pada anak di bawah dua tahun (Nugraheny, \& Amalia, 2017).

Ada 37 responden yang status gizi balita kurang sebanyak 29 responden (20\%) melakukan penyapihan dini, sedangkan dari 108 responden yang status gizi balitanya baik sebanyak 55 responden $(37.9 \%)$ melakukan penyapihan dini. Hasil uji chi square didapatkan nilai $p$ value 0,006 , artinya lebih kecil dibandingkan dengan nilai alpha $(0,006<0,05)$. Dengan demikian dapat disimpulkan secara statistik dengan derajat kepercayaan $95 \%$, diyakini terdapat hubungan status gizi dengan penyapihan pada anak di bawah usia 2 tahun. Sedangkan hasil uji OR diperoleh nilai $3,5 \quad(\mathrm{Cl} 95 \% \quad 1,2-6,1)$, artinya responden yang status gizi balita nya kurang berpeluang 3,5 kali lebih besar untuk melakukan penyapihan dini dibandingkan responden yang status gizi balitanya baik. Hal ini selaras dengan teori yang menunjukkan bahwa mayoritas ibu tidak mengetahui dampak dari usia penyapihan terhadap status gizi balita adalah semakin awal waktu anak disapih semakin banyak anak menderita kurang gizi karena ASI merupakan sumber gizi yang sangat ideal dengan komposisi yang seimbang karena disesuaikan dengan kebutuhan bayi pada pertumbuhannya. ASI adalah makanan bayi paling sempurna baik kualitas maupun kuantitasnya, bayi baru lahir secara alamiah mendapat zat kekebalan atau daya tahan tubuh dari ibunya melalui plasenta atau ari-ari. Tetapi kadar zat tersebut akan cepat menurun setelah kelahiran bayi (Proverawati \& Rahmawati, 2010).

Penelitian ini sejalan dengan penelitian tentang hubungan penyapihan dini dengan status gizi balita di Dusun Jambeyan Desa Banyurejo Tempel Sleman Yogyakarta diketahui Balita dengan status gizi baik sebanyak 32 orang (84\%) dan balita dengan status gizi kurang sebnayak 6 orang (16\%) dengan hasil fisher exact test menunjukkan $p=$ $0,038(p<0,05)$ ini menunjukkan adanya hubungan antara penyapihan dini dengan status gizi balita (Astuti \& Nawangsih, 2010).

Dari 78 responden dengan keluarga tidak mendukung sebanyak 55 responden $(70,5 \%)$ melakukan penyapihan dini, sedangkan dari 67 responden dengan keluarga mendukung sebanyak 29 responden (43.3\%) melakukan penyapihan dini. Hasil uji chi square didapatkan nilai $p$ value 0,002 , artinya lebih kecil dibandingkan dengan nilai alpha $(0,002<0,05)$. Dengan demikian dapat disimpulkan secara statistik dengan derajat kepercayaan $95 \%$, diyakini terdapat hubungan dukungan keluarga dengan penyapihan pada anak di bawah usia 2 tahun. Sedangkan hasil uji OR diperoleh nilai 3,1 (Cl 95\% 1,6-6,2), artinya responden dengan keluarga tidak mendukung berpeluang 3,1 kali lebih besar untuk melakukan penyapihan dini dibandingkan responden dengan keluarga mendukung.

Dukungan dari keluarga termasuk suami, orang tua atau saudara lainnya sangat menentukan keberhasilan menyusui. Karena pengaruh keluarga berdampak pada kondisi emosi ibu sehingga secara tidak langsung 
Faktor yang mempengaruhi ibu menyapih anak di bawah usia 2 tahun

mempengaruhi produksi ASI. Seorang ibu yang mendapat dukungan dari suami dan anggota keluarga lainnya akan meningkatkan pemberian ASI kepada bayinya. Sebaliknya dukungan yang kurang maka pemberian ASI menurun. Semakin banyak ibu yang mendapatkan dukungan dari keluarganya maka semakin besar ibu untuk menyapih anaknya pada usia $<2$ tahun karena alasan jika ibu yang mengalami bengkak pada payudara keluarganya menyuruh untuk menyapih anaknya saja (Haryono \& Setianingsih, 2014).

Hasil penelitian sejalan dengan penelitian tentang faktor - faktor yang berhubungan dengan penyapihan asi pada anak usia $<2$ tahun di Desa Kajar Kecamatan Lasem Kabupaten Rembang diketahui ada hubungan dukungan keluarga dengan penyapihan ASI pada anak usia $<2$ tahun. Hal ini ditunjukkan oleh $X 2$ hitung 6,170 $>X 2$ tabel 5,991 dan $\rho$ value $0,046<0,05$ (Wijayanti, 2016).

\section{SIMPULAN}

Dari 145 responden didapatkan kategori responden yang melakukan penyapihan dini yaitu sebanyak 84 responden $(57,9 \%)$, sedangkan yang tidak melakukan penyapihan dini sebanyak 61 responden $(42,1 \%)$. Rata-rata kategori responden usia reproduksi sehat (20-35 tahun) sebanyak 130 responden $(89,7 \%)$, sedangkan kategori pendidikan sebagian besar SMA sebanyak 74 responden $(51,0 \%)$. Responden yang bekerja yaitu sebanyak 39 responden $(26,9 \%)$, sedangkan responden yang tidak bekerja yaitu sebanyak 106 responden $(73,1 \%)$. Anak yang memiliki status gizi baik yaitu sebanyak 108 anak (74,5\%), sedangkan yang memiliki status gizi kurang sebanyak 37 anak $(25,5 \%)$. Serta responden dengan keluarga tidak mendukung yaitu sebanyak 78 responden $(53,8 \%)$, dan yang memiliki keluarga mendukung sebanyak 67 responden $(46,2 \%)$. Hasil uji statistik didapatkan nilai $p$ value $=0,025(p<0,05)$, nilai $O R=2,7$ yang artinya ada hubungan pekerjaan dengan penyapihan pada anak di bawah usia 2 tahun, didapatkan $p$ value $=0,006(p<0,05)$, nilai $O R=$ 3,5 artinya ada hubungan status gizi dengan penyapihan pada anak di bawah usia 2 tahun. Serta didapatkan nilai $p$ value $=0,002(p<0,05)$, nilai $\mathrm{OR}=3,1$ artinya ada hubungan dukungan keluarga dengan penyapihan pada anak di bawah usia 2 tahun.

\section{SARAN}

Dapat memberi gambaran dan menambah data tentang penyapihan di bawah usia 2 tahun serta sebagai bahan masukan serta evaluasi petugas kesehatan untuk meningkatkan pelayanan dan memberikan penyuluhan pada ibu menyusui agar tetap memberikan ASI seperti proses penyimpanan ASI selama bekerja dan perawatan payudara. Menjadi masukan serta evaluasi petugas kesehatan untuk meningkatkan pelayanan penyuluhan terhadap ibu menyusui mengenai penyapihan anak di bawah 2 tahun. Dapat menambah kepustakaan bagi mahasiswa, sehingga dapat menambah dan memperluas pengetahuan dan memberikan masukan materi kesehatan anak khususnya mengenai penyapihan anak.

\section{DAFTAR PUSTAKA}

Akter, S., \& Rahman, M. M. (2010). Duration of breastfeeding and its correlates in Bangladesh. Journal of health, population, and nutrition, 28(6), 595.

Astuti, N. W., \& Nawangsih, U. H. E. (2010). Hubungan Penyapihan Dini Dengan Status Gizi Balita Di Dusun Jambeyan Desa Banyurejo Tempel Sleman Yogyakarta Tahun 2010 (Doctoral dissertation, Universitas' Aisyiyah Yogyakarta).

Asuncion, A., \& Newman, D. (2007). UCl machine learning repository.

Badan Penelitian Statistik. (2018). Survei Demografi dan Kesehatan Indonesia (SDKI) 2017. Jakarta: Badan Pusat Statistik.

Dinas Kesehatan Kota Bandar Lampung. (2018). Capaian Indikator Standar Pelayanan Minimal (SPM). Bandar Lampung: Dinas Kesehatan Kota Bandar Lampung

Haryono, R., \& Setianingsih, S. (2014). Manfaat ASI eksklusif untuk buah hati anda. Yogyakarta: Gosyen Publishing, 1-30. 
Faktor yang mempengaruhi ibu menyapih anak di bawah usia 2 tahun

Hastuti, R., Muwakhidah, S. K. M., \& Dyah Widowati, S. K. M. (2016). Hubungan Umur Penyapihan Dan Pola Asuh Makan Terhadap Status Gizi Anak Balita Usia 25-36 Bulan Di Desa Purwosari Kabupaten Wonogiri (Doctoral dissertation, Universitas Muhammadiyah Surakarta).

Ifalahma, D. (2016). Hubungan pemberian susu formula dengan kejadian diare pada bayi usia 0-6 bulan di Puskesmas Mojolaban Sukoharjo. Jurnal Maternity, 3(2).

Manalu, A. (2008). Pola Makan Dan Penyapihan Serta Hubungannya Dengan Status Gizi Batita Di Desa Palip Kecamatan Silima PunggaPungga Kabupaten Dairi Tahun 2008.

Marmi, R. (2012). Asuhan Neonatus, Bayi, Balita, dan Anak Prasekolah. Yogyakarta: Pustaka Pelajar.

Monika, F. B. (2014). Buku pintar ASI dan menyusui. Jakarta: Noura Books.

Mubarak, W. I., \& Chayatin, N. (2009). IImu kesehatan masyarakat: teori dan aplikasi. Jakarta: Salemba Medika, 393.

Nugraheny, E., \& Amalia, R. P. (2017). Faktorfaktor yang berhubungan dengan waktu penyapihan pada anak di bawah dua tahun.

Nugroho, T. (2011). Buku ajar obstetri untuk mahasiswa kebidanan. Yogyakarta: Nuha Medika, 141-142.

Onyango, P., Celic, I., McCaffery, J. M., Boeke, J. D., \& Feinberg, A. P. (2002). SIRT3, a human SIR2 homologue, is an NAD-dependent deacetylase localized to mitochondria. Proceedings of the National Academy of Sciences, 99(21), 13653-13658.
Prasetyono, D. S. (2009). Buku pintar ASI eksklusif. Cetakan pertama. Jogjakarta: Diva Press (Anggota IKAPI).

Proverawati, A., \& Rahmawati, E. (2010). Kapita selekta ASI dan menyusui. Yogyakarta: Nuha Medika, 9, 13-17.

Putri, D. A., \& Zubaidah, Z. (2017). Hubungan Dukungan Keluarga dengan Usia Penyapihan ASI di Desa Rowosari Tembalang Kota Semarang (Doctoral dissertation, Faculty of Medicine).

Roesli, U. (2012). Panduan: inisiasi menyusu dini: plus asi eksklusif. Pustaka Bunda.

Soetjiningsih, S. (2004). Tumbuh Kembang Remaja dan Permasalahannya. Sagung Seto. Jakarta, 320.

Supariasa, I. D. N., Bakri, B., \& Fajar, I. (2012). Penilaian Status Gizi Edisi Revisi. Jakarta: Penerbit Buku Kedokteran ECG.

United Nations Children's Fund. (2018). WHO, World Bank Group. 2017. Levels and trends in child malnutrition.

Wawan, A., \& Dewi, M. (2010). Teori dan pengukuran pengetahuan, sikap dan perilaku manusia. Yogyakarta: Nuha Medika, 11-18.

Wijayanti, I. T. (2016). Faktor-Faktor Yang Berhubungan Dengan Penyapihan Asi Pada Anak Usia< 2 Tahun Di Desa Kajar Kecamatan Lasem Kabupaten Rembang. Jurnal IImu Kebidanan dan Kesehatan (Journal of Midwifery Science and Health), 7(2). 